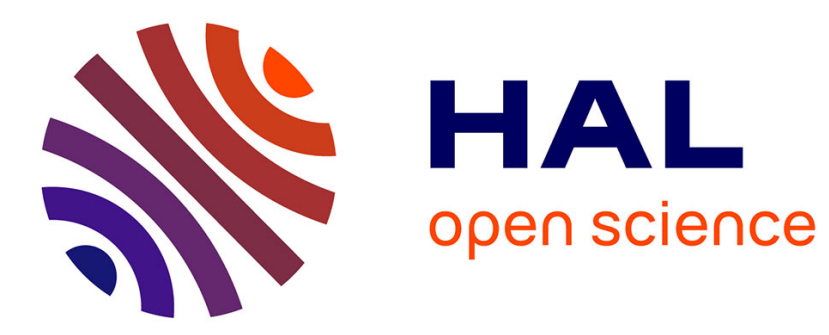

\title{
Coordinating Transport and Urban Planning: From Ideologies to Local Realities
}

Caroline Gallez, Vincent Kaufmann, Hanja-Niriana Maksim, Mariane

Thébert, Christophe Guerrinha

\section{- To cite this version:}

Caroline Gallez, Vincent Kaufmann, Hanja-Niriana Maksim, Mariane Thébert, Christophe Guerrinha. Coordinating Transport and Urban Planning: From Ideologies to Local Realities. European Planning Studies, 2013, 21 (8), pp.1235-1255. 10.1080/09654313.2012.722945 . halshs-00730339

\section{HAL Id: halshs-00730339 \\ https://shs.hal.science/halshs-00730339}

Submitted on 19 Mar 2018

HAL is a multi-disciplinary open access archive for the deposit and dissemination of scientific research documents, whether they are published or not. The documents may come from teaching and research institutions in France or abroad, or from public or private research centers.
L'archive ouverte pluridisciplinaire HAL, est destinée au dépôt et à la diffusion de documents scientifiques de niveau recherche, publiés ou non, émanant des établissements d'enseignement et de recherche français ou étrangers, des laboratoires publics ou privés. 
Article paru dans European Planning Studies, 2013, 21(8), pp. 1235-1255.

\title{
Coordinating transport and urban planning: from ideologies to local realities
}

Caroline Gallez

LVMT-IFSTTAR, University Paris East, Marne-la-Vallée, France

caroline.gallez@ifsttar.fr

Vincent Kaufmann

LaSUR-EPFL, Lausanne, Switzerland

vincent.kaufmann@epfl.ch

Hanja Maksim

LaSUR-EPFL, Lausanne, Switzerland

hanja.maksim@epfl.ch

Mariane Thébert

LVMT-IFSTTAR, University Paris East, Marne-la-Vallée, France

marianne.thebert@enpc.fr

Christophe Guerrinha

Conseil Régional Languedoc-Roussillon, Direction des Transports et des Communications, Montpellier, France

guerrinha.christophe@cr-languedocroussillon.fr

\begin{abstract}
In Europe, the idea that coordinating transportation and urban planning is a necessary condition for setting sustainable urban development into motion has spread throughout academic and professional circles. While this concern is not new, the objectives underlying transport and urban planning coordination have deeply changed over the last decades. How have local authorities translated the requirements and objectives of national laws? How have they accounted for the evolution of these global objectives? What factors explain innovation and continuity in the relationship between land use planning and transport policies? In a comparative research between Switzerland and France, we addressed the question of political change by reconstituting the "trajectories" of four urban areas: Geneva and Bern in Switzerland and Strasbourg and Bordeaux in France. We have described the policy paths of these urban areas since the end of the 1960's by focusing on the contents of master plans, the principal technical solutions and projects that have been implemented, and the means of inter-sectorial coordination used. For each case, factors of change or inertia have been identified by focusing on three main variables that are often studied alternatively in public policy analysis: ideas, institutions and interests.
\end{abstract}

Keywords: urban planning; transport policies; coordination; public policy change; ideas; institutions; interests

\section{Introduction}

In Europe, the idea that coordinating transportation and urban planning is a necessary condition for setting sustainable urban development into motion has spread throughout academic and professional circles. This idea is largely supported by the observation that the only metropolitan areas which have succeeded in containing urban automobile use (Basel, Bern, Zurich, Karlsruhe...) are those which combine public transport development with various kinds of automobile use restrictions - notably parking restrictions - as well as urban 
planning and development measures - proximity-based urbanism, urbanization and densification around public transport stations, etc. (Apel and Pharoah, 1995; Brög, Erl, Raux and Jones, 1996) ${ }^{1}$. The success of these coordinated policies is generally measured by public transport's mode share. In the metropolitan areas of Basel, Bern or Zurich, the percentage of trips by public transport was around $23-24 \%$ in the mid-1990s, which was $30 \%$ to $50 \%$ higher than in French urban areas of the same size (Jemelin, Kaufmann, Barbey, Klein, Pini, 2007).

In the field of urban planning, the question of the relationship between transport networks, the organization of traffic flows, and urban form is certainly not a new one, as shown by the formalizations elaborated at the end of the 19th century by Haussman and Cerdà, and in Madrid urbanist Arturio Soria y Mata's famous linear city project (Ciudad Lineal). However, the issues underlying this problem have changed greatly, as have lifestyles and urban travel in general. Considering just the last fifty years, we have gone from a vision where automobile travel had a hegemonic role in the city to one where values of urbanity, road surface sharing, and mixed-use public space serve as the basis for roadway design (Wachter, 2003). In academic debate, questions surrounding the relationship between transport network development, urban growth, and economic development, often evoked in terms of the "structuring effects" of transport (Offner, 1993), have become both more modest and more ambitious: more modest, in the sense that network development is now considered to be one factor among many in these transformations; more ambitious because we now consider the political regulation of these interactions (Offner and Ollivier-Trigalo, 2000).

Despite a consensus that it is necessary to better coordinate mobility management with the development and organization of urbanized spaces, debate over the objectives and means behind this coordination remains relatively limited. In this research, we have examined the actors in charge of urban travel and development in several French and Swiss metropolitan areas, and addressed questions about the relationship between the city and transportation over the last fifty years (Gallez and Kaufmann, 2010). How has the shift in perspective - from adapting the city to the automobile toward promoting sustainable cities and mobilities - been translated into action? And what of local issues, visions, and coordination practices surrounding transportation and urban planning? What factors favor this kind of integration, and can we identify sources of inertia and causes of public action fragmentation?

To respond to these questions, we have employed diachronic studies of four metropolitan areas: Bern and Geneva in Switzerland, and Strasbourg and Bordeaux in France. In this sample, Bern and Strasbourg serve if not as models, at least as references for the integration of urban planning and travel policy (for the former), and the implementation of multimodal travel policies (for the latter). On the other hand, the dominant role of the car in urban development models has been questioned more recently in Geneva and Bordeaux.

This paper is divided into six sections. First, we briefly present the four study areas, in terms of their spatial and demographic characteristics. Then, we describe the methodology and choice of analytical framework. The three following sections review the factors of continuity or change identified in the four study cities, from three complementary entry points: institutions, interests, and ideas. The last section tackles the question of interdependences between the three dimensions of analysis and underlines the importance of the local context. Finally, the conclusion draws up the principal lessons drawn from the cross analysis of urban trajectories. 


\section{Main contrasts in urban areas of Bern, Geneva, Strasbourg and Bordeaux}

The four urban areas differ in terms of their geographic location, size, and population distribution. In order to clarify the scope (and limits) of our comparative study, we will briefly present some elements of context.

Geographic location and topographic constraints have strongly influenced urban development in these four metropolitan areas.

Bordeaux is situated in the southwest of France, at the mouth of the Garonne River. Other than the presence of large vineyards, which have lead to unequal urbanisation of the river's two banks, there is a lack of topographic constraints to constrain urban development (figure 1). The urban region ${ }^{2}$ of Bordeaux, which had almost one million inhabitants in 2006, is one of the most sprawling in France (table 1).

With 122,422 inhabitants in the centre and 350,000 in its urban region, Bern is the smallest European capital, and also the smallest of the four cities in our sample. The capital of the Helvetic Confederation has developed in a series of meanders on the Aar River (figure 2). The historic centre is entirely contained by one of these loops, and access conditions are thus practically those of a peninsula.

Strasbourg and Geneva are cross-border conurbations with very different topographic contexts.

The Strasbourg conurbation is situated in the plain of Alsace, with urbanisation constraints linked to hydrographic conditions and the existence of ancient military roads (figure 3). The Strasbourg urban region is much less spread out than that of Bordeaux $\left(965 \mathrm{~km}^{2}\right.$ versus 2,872 $\mathrm{km}^{2}$ ), and has just over 612,000 inhabitants. Peripheral urban development is structured around many small towns and cities, and was contained by the presence of vineyards.

The canton of Geneva's territory is both very small $\left(246 \mathrm{~km}^{2}\right.$ without the lake) and almost entirely surrounded by France (figure 4). This city has developed at the southwest end of Lake Geneva, within a basin surrounded by several mountain ranges, most of which are in France (in the Jura and Haute-Savoie). Using the French definition, the Geneva urban area has a just under 700,000 inhabitants, around 250,000 of whom live in France.

Because of salary and land price differentials between France and Germany (for Strasbourg) and France and Switzerland (for Geneva), national borders have played a very different role in these two cross-border conurbations. Strasbourg essentially exerts its force of attraction within its own country, whereas most of Geneva's periurban development occurred outside the canton of Geneva, on the French side of the border. Because of this, cross-border flows are much more significant in the Geneva region than in Strasbourg-Ortenau. Commuter trips are primarily centrifugal in the first case (from the Strasbourg region outward) and centripetal in the second (from France or the canton of Vaud toward Geneva).

\section{Changes in urban trajectories: the "Three I's" analytical framework}

Switzerland is one of the European countries which, in a few urban areas over the last thirty years or so, have practiced action strategies coordinating transportation and urban planning. In Basel, Bern, and Zurich, these policies seek to reduce urban automobile use by increasing public transport supply while structuring urban development around this supply and limiting car access to the city centre. The example of major urban areas in German-speaking Switzerland has been widely publicized in the media as a "best practices" by European urban transport professionals ${ }^{3}$. This situation has encouraged the export of expertise and measures 
inspired by the Swiss model: numerous major cities and French (for instance Grenoble, Strasbourg or Orléans), German, and Italian urban regions refer to it, relying on Swiss engineering and planning firms to apply these principles locally. Comparative studies of urban projects in Basel, Bern Geneva and Lausanne identified various kinds of "ingredients" which play a part in the coordination of sectoral policies in German-speaking urban areas, such as values underlying political choices, favourable morphological conditions (e.g. preexisting train lines), or federal or national laws with financial conditions encouraging coordination (Kaufmann, Sager, Ferrari and Joye, 2003). Other observations made at the European level highlighted local differences in political opportunities, structures and instruments, importance of the car as a status symbol, and the weight of past decisions on the present as restrictive conditions for the export of best practises ${ }^{4}$. In the case of Switzerland, the weight of local factors is evidenced by the fact that the German-speaking model has not yet been successfully exported to other Swiss cities such as Geneva and Lausanne.

From a methodological point of view, comparing urban policies at one particular moment gets into problems due to differences in urban structures and institutional organizations. Structural factors may be identified as barriers to the export of public policy, even though their effects have not been studied in the long term. Rather than addressing the question of transferability of best practices, which implies a normative view of urban planning and transport coherence (where one city serves as the "model"), we decided to focus on the question of policy change.

We chose a dynamic approach of urban policies which allowed us to identify for each urban area the conditions that either prohibit or encourage change by altering how problems are formulated or how these two sectors of public action are coordinated. To do so, we have reconstituted these four cities' urban planning and transport policy trajectories over the last forty years. By trajectory, we mean the path taken through changes in these sectors' issues and orientations, organizational mechanisms, procedures, and regulatory instruments, as well as the principle means employed at different spatial scales (from the centre city to the entire urban region.)

Recent work in the field of political science has underscored the importance of analyzing public policy changes over the long term. According to Fontaine and Hassenteufel (2002), this historic distance allows us to better describe changes by bringing out the inertial and continuity factors characteristic of public action processes, as well as interaction between the different decisional echelons, notably the local and national scales. This temporal perspective of analysis appears to be particularly appropriate for our problem, as the transport and urban planning coordination issues have persisted throughout the entire period, while referring to objectives and means of action that a priori (i.e. if we judge by the legal texts and administrative circulars which define them) have changed profoundly.

To compare the results of our different case studies, we have opted for the analytical framework referred to as the "three I's" in the field of public polices analysis. This allows us to combine three complementary classic entry points for the analysis of public policies: Ideas, Institutions, and Interests, which are often approached independently of one another (Palier and Surel, 2005). Ideas refers to the intellectual dimension of public action: the values, beliefs, and norms which influence the formulation of problems and the choice of political solutions. Institutional logic refers to the manner in which formal action frameworks (laws, institutional organization, and procedures) influence the individual decisions. We attempt to identify the cumulative effects of these mechanisms and decisions. Finally, interests refers to the strategic dimension of public action, that is to say, the manner in which actors formulate their objectives and their demands, negotiating representation and putting strategies into place to defend them. 
These three dimensions were first applied successively to the four study sites with no a priori hierarchy. Reconstructing the different phases of their urban trajectories then allowed us to show the dominant role of factors belonging to one or several of these three dimensions over each period. In this paper, we will concentrate on these local dynamics, which served as a basis for our comparative analysis.

\section{Ideologies and local traditions in the relationship between transport and the city}

At first glance, these four urban areas' trajectories reveal coherent changes in the ideas, values, and norms underlying the logic of local urbanism and transport actions. In the movement from the automobile city toward the sustainable city, similarities in the arguments justifying the foundations of public intervention attest to the strength of certain general doctrines, which have spread widely through international professional circles. Nonetheless, a more in-depth analysis reveals a certain number of ideological differences between France and Switzerland, which have more or less pronounced effects at the local scale.

\section{Visions of urbanity and territorial development}

Urban planning and development policies in Switzerland and France refer to visions of the urban phenomenon that were initially quite divergent.

In Switzerland, the beginnings of urban planning were influenced by anti-urban ideologies, associated as much with moral considerations ("the city is bad for mankind") as a rejection of the political domination of the countryside by cities (Salomon Cavin, 2005). This reserved attitude of the Swiss Confederation toward the urban phenomenon can be interpreted, on the political front, as a result of federalist organization founded on the strict respect of cantonal autonomy. On the ideological side, we also find a clear influence from the ruralist doctrines characteristic of the first half of the 20th century (Walter, 1994) in the roots of planning policies. A federal law on the protection of agriculture was created in 1952. It refers to the principle of agricultural self-sufficiency, and helped agriculture take its place as a privileged sector of the economy after 1940. Up until very recently, neither planning policy nor regional policies supporting struggling territories took urban areas into account.

The rarity of land and the protection of agricultural spaces solidly imposed themselves as organizing principles in the domain of territorial development and planning, notably in the most confined spaces, like that of the canton of Geneva. The first cantonal master plans sought to densify urbanization within a central zone delimited by an agricultural green belt, which has been strictly protected since 1952. The effects of this protectionism on the coordination of urban planning and transport vary according to the time or urban area considered. Within the limited and densely populated territory of the Geneva canton, the accent was placed on the development of an intensive public transport network, and by 1925 , the canton of Geneva thus possessed one of the densest tramway networks in Europe. Almost entirely dismantled in the 1950s to make space for the automobile, it has been replaced by a network of busses, trolleys and motor coaches that is equally effective. However, this strategy of densification and short-distance service was not accompanied by restrictions on car use as it was in Bern. On one hand, there exists an old but living tradition automobile use in Geneva, as evidenced by the physiognomy of the city (car access is not really restricted, even in the city centre) and the polemics which even today enter into debates on the place of the car in the city (even today, car supporters actively confront ecological associations). On the other hand, interurban accessibility to this internationally prominent financial centre is essentially provided by the road and motorway network rather than rail connections, which have long been judged unnecessary to the canton's functioning. Nevertheless, increases in cross-border 
travel over the last two decades tend to challenge this original "dense automobile city" model, as much of Geneva's periphery lies outside the canton in France.

In France, urban questions are an essential part of the national territorial development policy, which was put in place in the 1960s. Here the major issue was not limited available land, but rather the balance between major urban areas and the redistribution of economic growth. This vision is based on both Malthusian principles concerning the growth of the Parisian region and the desire to support the development and equipment of major towns outside the capital. The urban planning and development schemes (SDAU) of the 1970s and the "new towns", which were intended to polarize peripheral urban development, employed a very hierarchical approach to urban structure. Urban planning was also dominated by a functionalist approach, relying on zoning and the principle of hierarchy in traffic flows.

In urban planning practices in Strasbourg and Bordeaux, we see both the influence of these national planning doctrines and nuances in their local implementation. During the 1960s and 70s, planning documents and decisions regarding transport infrastructure in the Strasbourg area reveal two opposing views on the relationship between the city and transportation. The first, which was based on traffic model and accessibility experiments carried out by transport engineers in cooperation with the Transport Ministry, evaluated the need for transportation (primarily road) infrastructure based on projected urban growth ${ }^{5}$. The second, developed within the planning services of the city of Strasbourg, is coherent with local urban history and its German heritage. It refers to a culturalist vision of planning which is particularly attached to the defence of architectural heritage and a clear distinction between urban and rural environments.

\section{The ambiguous role of ecology}

The idea that the success of transport/urbanism coordination strategies can be explained by the strong legitimacy of ecological values in the Swiss German-speaking metropolitan areas is fairly common ${ }^{6}$. However, as shown by previous work comparing several Swiss urban areas (Kaufmann et alii, 2003), the analysis of our four urban areas' trajectories requires us to nuance this argument.

In Switzerland, environmental awareness as a global approach emerged on the national political scene at the beginning of the 1980s, in the context of "acid rain" episodes that were widely covered by the media, provoking a special session of the Helvetic Confederation's parliament. This preoccupation takes root in an existing tradition of landscape conservation born out of the confrontation between the two (aesthetic and economic) functions of nature, and a desire to identify the homeland with the alpine landscape (Walter, 2005). In the transportation and urban planning, this turn in environment policies are twofold. First, the reduction of pollution appears among the objectives of the extension and modernization project for railway infrastructure, RAIL 2000, which sought to develop a supply of intermodal and well-connected public transport. Second, the federal environment protection law (LPE) of 1983 is accompanied with the definition of noise and pollution norms, which limited urban development in zones exceeding certain thresholds.

In France, environmental protection was taken into account much later by the urban and transport planning fields, at least on the national scale. The text of the 1996 law on "air and the rational use of energy" addresses environmental concerns almost exclusively through modal shift from the car toward public transport, walking, and the bicycle. Openness to environmental problems varied from one place to another, but was rarely focussed on urban and travel questions. In the 1970s in Strasbourg, the strongest movements addressed national or regional issues such as nuclear power and industrial development along the Rhine in the greater Strasbourg region. In Bordeaux, it was not until the conflict surrounding the VAL 
automated metro project in the 1980s that ecologists turned toward transportation and took an active part in debates. Nevertheless, the battle was less about modal shift or urban structure issues than financial costs. With the creation of a Green Plan for Strasbourg in 1974, which sought to improve a system of green spaces within the urban area, ecology advanced into the field of urban planning in a way that was original (this process had no equivalent in France at the time) but restricted. The relative disconnect between urban and ecological issues limited public intervention to a few isolated cases geographically targeted on centre cities, which were subject to the most important degradation.

Though the weight of environmental questions in the promotion of alternative modes to the private car seems indisputable, its role in the implementation of urban planning-transport coordination policies seems more ambiguous. An analysis of the urban travel plans (PDU) required by the Air Law in France has already pointed out how weak local interpretations of the new public action referential, i.e. urban air quality and the rational use of energy, can be (Offner, 2003). This lack of coordination is likely due in part to the important role played by zones (agricultural or natural zones, risk zones) in classic environmental protection policy, which is somewhat incompatible with reticular (i.e. network-oriented) urban planning. For example, applying noise and pollution standards to construction in Swiss urban areas often meant paradoxically locating noisy or polluting industrial activities far from residential zones. In order to avoid this sort of effect, the Bern canton recently created a "travel weighting" criterion, which takes the traffic generated by new industry into account for location choice.

\section{Coordination and institutional frameworks: between flexibility and inertia}

The role of ideas in the change of transportation and urban planning strategies is limited by existing institutional framework, which organizes and constraints decision process.

The creation of integrated authorities, acting within a jurisdiction considered "pertinent" for problems regarding the development, organization, and attractiveness of major urban areas is often presented as an essential prerequisite for coordinated urban policy ${ }^{7}$. We have found the comparison of Switzerland (a federal state) and France (a nation-state that has progressively decentralized power) to be particularly useful in testing such an assertion. Here we present two specific results of this comparison.

\section{The existence of an integrated transport and urban planning authority is not sufficient to set coordinated policies into action}

This observation principally concerns the two French urban areas, Strasbourg and Bordeaux, which were given the status of Urban Communities (communautés urbaines) by the State at the end of the 1960s. Despite the resultant cooperative, integrated inter-municipal structures, there has been no real coordination of transport and urban planning policies at a regional scale. The municipalities retained most decisional power in urban planning, while the regional institution served to develop urban transportation services and manage a certain number of major roadways. Parking and local roadway maintenance are generally municipal responsibilities. This geographic and technical separation of responsibility has been strengthened by local elected officials' resistance to the creation of cooperative structures, which were imposed by the State. In both cases, a political pact founded on the principle of non-interference by the Urban Community in municipal affairs has managed to neutralize any requirements for cooperation. This kind of consensual operation yields an absence of planning priorities at the regional scale.

In Strasbourg in particular, the defence of municipal prerogatives was for a long time reinforced by a desire to maintain an exceptional construction law regime inherited from German law, in which the Mayor of the centre city has quasi-monarchic power. Pierre 
Pfimlin, president of the Urban Community and mayor of Strasbourg until 1983, was strictly opposed to the replacement of these unique municipal construction laws by common law. In conformity to the 1967 land use law ${ }^{8}$, Strasbourg's land use plan (POS) procedure was launched immediately after the approval of the master plan in 1973; but it took nearly twenty years to complete. The process was hijacked in various ways, even leading to convictions in the administrative courts. At the beginning of the 1990s a municipal team led by Catherine Trautmann re-launched planning procedures and finally secured rapid approval of the POS, without which it would have been impossible to construct the new tramway. Despite this step toward coordination, the Urban Community, though legally responsible for elaborating a collective Local Urban Plan (PLU), continues to delegate this task to the 27 member municipalities. Though the tramway is indeed an inter-municipal project intended to improve accessibility for the entire Strasbourg region, it is not connected to a shared urban development project at the overall Urban Community scale.

In the case of Geneva, segmentation of responsibilities is also quite visible, but unlike the two French study areas, this fragmentation is less geographic than technical. In fact, the canton of Geneva is one off the Swiss cantons where municipal autonomy is the weakest, and municipal influence on urban planning and transportation is quite limited. Because of its limited territory, the cantonal institution got involved very early in the field of territorial development, concentrating all planning and transportation functions at its level. Several master plans have been created since the 1950s, even before the Helvetic Confederation made this a legal obligation in its 1979 law on territorial development (LAT). Despite this technical and geographic integration, procedures and projects were increasingly sectorialized over the course of the 1980s, particularly in the transportation field. A revival of traffic and modal shift policy in the canton of Geneva at the beginning of the 1990s (Circulation 2000) made no reference to urban planning problems. From this time forward, transportation and land use plans, which were previously both part of the cantonal master plan, were created separately (Kaufmann, Säger, Ferrari and Joye, 2003).

\section{Coordinated transport and urban planning policy can emerge in the absence of integrated regional-scale institutions}

As in most other Swiss cantons, municipal autonomy is more pronounced in the canton of Bern than in that of Geneva: municipalities are responsible for territorial development, as well as the organization of urban transport and parking. The canton of Bern is also unique in that it includes several development regions, which emerged in the 1970s as communal associations involving almost every municipality in the canton. The Bern urban region association of municipalities, which adopted the name Verein Region Bern (VRB) in 1991, saw its prerogatives progressively extended over this period. Nevertheless, institutional reform giving the association greater power to address regional development problems was not begun until the 1990s, without changing the principles of free association and municipal autonomy. Any attempts to do otherwise were immediately met with strong opposition from citizens and elected officials. At the same time, following the 1993 law on public transport, the canton of Bern launched regional transport conferences in order to improve public transport supply coherence at different scales, and encourage coordination between public and private transport. The Bern Transport Conference (RVK4) was created in 1994 and includes 89 municipalities.

Integrative institutional reform thus appeared after coordination, which emerged in the 1980s in both planning practices (at the regional and cantonal scales) and the outlining of projects. In Bern, the progressive institutionalization of land use-transport coordination was the result of a compromise between the effectiveness of structures and the defence of local democracy. 
In fact, any increase in regional power was systematically checked by the introduction of citizen participation rights and the retention of municipal independence.

\section{Conflict, negotiations, and compromises around the city-transport connection}

Seen from the perspective of individual and institutional strategies, the coordination of urban planning and transport involves tensions, misalignments, and conflicts of interest that characterize the coexistence and joint development of transport networks, travel flows, and urbanization. From this perspective, we see coordination as local actors' attempts or strategies to regulate these mismatches, tensions, and conflicts.

Beginning with the classic opposition between two visions of urban production, that which privileges centrality (the areolar approach) and that which accentuates the development of networks (the reticular approach), we first seek to identify which kind of interests refer to each of these conceptions, and to understand their role in the evolving relationship between the city and transport. Next we will question the weight that economic reasoning carries in the process of land use and transport policy coordination, from the example of the cross-border territories.

\section{Networks vs. territories?}

The development of networks and the diversification of mobility brought politicaladministrative boundaries into question, threatening to dispossess political powers whose legitimacy was built on a delimited territory (Offner, 2000). How then was coordination established between urban planning, whose approach remained fundamentally forged by the areolar vision of territories, i.e. that defined by zones and borders, and transport planning, which refers to the reticular approach in which networks and flows constitute the urban?

In questioning the importance of an approach "which relegates networks to the subaltern function of circulatory technology" within the field of urban planning, Gabriel Dupuy (1991) returns to the emergence of urban planning practices at the end of the 19th century, when urbanists' desire for reform ran up against opposition from landed property owners, who were careful to preserve as much of their land rent as possible (Gaudin, 1989). In this context, zoning gradually appeared as a means to justify public action and clarify the rules for landowners. Expropriation through zones allowed both real estate prices and housing densities to be controlled. In other words, the areolar and reticular points of view correspond to somewhat antagonistic interests which, in different periods and under different degrees of tension and discord, resulted in either the reinforcement of border logic or the networking of territorial interests.

Two of our case studies show the importance of conflicts between these two perspectives in the production of urban planning practices. These conflicts of interest affect both how problems are formulated and how concrete solutions are implemented, for both integrated technical solutions and cooperative practices.

For example, the 1975 plan to create a pedestrian-only area and a tramway in the centre of Strasbourg was the result of a compromise between the political vision of the municipal administration, which was motivated by the defence of architectural heritage and the reconquest of central public space, and the objectives of national technical authorities, which were expressed in terms of road accessibility improvement. Despite the fact that this project was postponed for political and economic reasons (poor acceptance of the tramway, a temporary reduction in State transport subsidies, and the business owners' hostility toward eliminating automobile traffic from the centre), it was a major step forward in the local consideration of urban planning and transport interaction. At the beginning of the 1990s, the 
tramway project was re-launched using almost exactly the same right of way that was defined at the beginning of the 1980 s.

Urban planning and transport coordination strategy in the canton and urban region of Bern is particularly interesting. Everything starts in 1972, after a project of urban motorway has been rejected by "popular voting" (votation populaire), in the name of the defence of quality of life. Two places in the city centre were closed to car traffic. In the first decade following this decision, the municipality of Bern adapted public transport supply and car traffic regulation to these new access constraints. Facing the increase in car traffic due to urban sprawl, these measures proved insufficient. During the 1980s, becoming aware of the problem raised by the outflow of inhabitants towards the periphery, the Bernese authorities started to review their transport and urban development strategies and to explore how to adapt car traffic to the city (and not the other way around). The main purpose set out in the report "Environment, City, Transport" of 1982 was to maintain the quality of life and attractiveness of the centre city to counterbalance the appeal of the periphery. In the third act, at the end of the 1980s, the canton of Bern enters the scene. Considering the lack of building land in areas well served by public transport, the canton initiated the policy of the "poles of economic development" (PDE), which aims at planning and facilitating economic development closed to the nodes of S-Bahn network. This was the beginning of coordination between transportation and urban planning at the canton's and VRB scales, as attested by the production of numerous studies, reports and planning documents during the 1990s.

Though local actors readily declare that spatial planning and transport have been coordinated for thirty years in Bern, the history of local policies shows that coordination is an ongoing and conflictual process. It seems that the memory of this process has faded with time, aided by simplifications accompanying the spread of the "Bern model" in technical circles. The reconciliation of transport and urban planning objectives was the result of progressive changes in scale, from the centre city to the urban region to the canton.

\section{The economic logic of territorial dialogue: the special case of cross border territories}

History shows that economic reasoning carried significant weight in the development of urban technical networks, whose emergence owes much to private interests and initiative. In fact, these networks first extended their reach wherever "demand was solvent" (Dupuy, 1991). Urban landowners were generally opposed to their extension elsewhere, where these networks might induce new urbanization and create real estate value. This close correlation between network development and urban density explains why networks initially had minimal impact on urban morphology.

The rise of individual motorization in the 1950s spread access to urban road networks and thus accelerated metropolitan areas' changes in scale. Improved travel conditions altered the trade-offs made by individuals, households, and businesses by greatly increasing their opportunities within urban space, both in terms of real estate and workplace or activity choices. By weakening proximity constraints, increases in speed became an essential factor in the peri-urbanisation of habitat and activities (Wiel, 2002). Depending on context and time period, different lines of economic reasoning either sustained or slowed down the resultant expansion and fragmentation of cities.

The case of urban regions that span borders is unique in that salary, tax, and land price differentials have a direct impact on commuting flows, the formation of interest groups, and the kinds of confrontation that emerge between them.

From the point of view of city-transport coherence, the weight of economic reasoning appears to be relatively weak in the construction of a cross-border cooperation between the Strasbourg 
urban area and Kreis d'Orteneau, compared to what we observe in the Franco-Swiss case of Geneva. The recent arrival of the TGV high speed train line in Strasbourg reinforces the priority accorded to interurban connection projects: it is at this scale, more than that of the cross-border employment basin, that State subsidy requests are focussed. This follows from rhetoric that emphasizes Strasbourg's position as a "European crossroads", referring to its role as the political capital of the European Union (Ollivier-Trigalo, 2007).

In Geneva, urban spatial and travel questions are quite present in the history of relationships between Swiss and French municipalities. Growing dysfunction in Geneva's transport system oriented cantonal priorities toward the improvement of public transport during the 1980s, and was an integral part of establishing the cross-border scale of the Geneva metropolitan area.

Since the end of the 1980s, the acceleration of urban sprawl has been accompanied by a strong increase in commuting flows between Switzerland and France, and pushed Geneva's access roadways to saturation. The creation of a heavy rail public transport system between Switzerland and France thus became a particularly pressing issue, and was integrated into the project to create a regional express network in the 1990s. A new actor called Transborder Economic and Social Coordination (CEST) intervened on the local scene, and was decisive in initiating Franco-Swiss negotiations on the implementation of cross-border public transit service. This organization, which sought to encourage concertation between labour unions on either side of the national border, defended the specific interests of cross-border workers according to a reticular logic, attempting to lessen the hermetic character of national borders. Despite effective mediation, negotiations between the canton of Geneva and the municipalities of the Annemasse urban area stalled when both parties refused to finance the line. In 1992, Switzerland's referendum decision against European Union membership accelerated cross-border cooperation. However, it was not until the beginning of the 2000s that the rail line project between Geneva and Annemasse (CEVA) was re-launched.

We can conclude that strategic territorial planning efforts undertaken over the last ten years probably demonstrate a common desire of Swiss and French authorities to advance crossborder cooperation. The interplay of interests is shifting, and French municipalities are asking that employment opportunities spread to their territory in exchange for contributions to public transport supply improvement. However, the brusqueness with which the canton of Geneva has taken the initiative on the CEVA project does not facilitate negotiations ${ }^{9}$. Discussions involve the Rhône-Alpes Region and the French State rather than the French municipalities, which do not have decisional power over rail services. When faced with French hesitation to participate in financing, the Geneva canton recently threatened to stop contributing to the "Geneva fund" 10 . Thus it seems that the future of CEVA, a spearhead of cross-border development policy, is not entirely sealed.

\section{Local context and interactions between ideas, institutions and interests}

Using the «Three I's » analytical framework, we have discussed the effects of three classical starting points for public policy analysis on changes in four urban areas' urban planning and transport policy trajectories. This kind of analysis is useful for comparing the general results of several diachronic studies. However, it neglects the interdependencies between the three analytical dimensions highlighted in each of the case studies.

In order to give deeper consideration to the question of political change, we will now return to the most significant interdependances (according to our four case studies), institutions and interests on one hand, and ideas and interests on the other. 
Furthermore, we will highlight the influence of urban and socio-demographic factors - briefly described in the first section of this article - on the way actors formulate public problems and get involved in coordination strategies.

\section{Institutions: constraints on actors and their resources}

In political science, the concept of institution has been appearing more and more frequently over the last two decades. Works referring to the new institutionalism approach this notion in different ways and assign quite different meanings to it (Hall and Taylor, 1996). In our research, we have focused on analysing local institutional orders, examining the role of these technical and political frameworks on changes in urban planning and transport policy. By reconstituting urban trajectories over a forty- year period, we were able to show how this influence is closely connected to local actors' strategies.

On the one hand, actors' capacity for negotiation depends on the institutions they serve. For instance, Strasbourg's mayor Pierre Pfimlin successfully opposed several state road projects during the 1970s thanks to an exceptional construction law regime inherited from German law, which granted him full authority over urban planning within his own territory. Actors' capacity for negotiation is not completely determined or constrained by institutions, insofar as they sometimes act beyond the responsibilities or the legal framework of their own institution. Such extensions beyond the legal limits are generally justified by the need to solve complex social problems and a necessity to adapt as closely as possible to the local context (Faure and Douillet, 2005). In other words, changes in practises often precede changes in institutional organization or the legal framework, as illustrated in the Bern case, where actors began to coordinate at the urban region scale before urban planning powers of Verein Region Bern were increased. In some cases, local practises come before changes in national or federal law, as shown by the Geneva example, where actors got involved very early in urban planning, due to the canton's territorial constraints.

On the other hand, the efficiency and functioning of institutions depend greatly on local actors' strategies. In the two French urban areas, political pacts were made among local actors in order to prevent the Urban Communities from becoming «supra-municipalities » capable of imposing decisions on municipalities in the name of higher public interest. This consensusbased mode of operation greatly influenced political choices in the field of urban planning and transport (e.g. inability to define urban development priorities, significant extension of the public transport network towards peripheral areas in the case of Bordeaux). Specifically in the Bordeaux urban area, the absence of topographic or legal constraints on urban development maintained the general principle of action that prevailed in the 1960s, according to which transport infrastructure should adapt to urban expansion and growth in the number of trips.

\section{Ideas into action}

The existence of interdependencies between ideas and interests supports the hypothesis that the manner in which an idea imposes itself in the political domain depends on the concrete conditions under which power is exercised. This hypothesis is foundational in cognitive approaches to public policy (Muller, 2000; Zittoun and Demongeot, 2009). Several examples taken from our study cases demonstrate the existence of such interdependencies.

In Bern at the beginning of the 1970s (as in many other European towns during the same period), supporters of ecological values and people concerned about quality of life issues were confronting others who were convinced that economic and social progress would depend on the car. The four-lane urban project known as H-Lösung was rejected largely because for this particular project, the balance of power between the "anti-" and "pro-car" groups was favourable to the former ${ }^{11}$. Following a referendum, the municipality of Bern decided to close 
two places in the city centre to car traffic. This reduced access to the city centre compounded the existing site-specific constraints created by the Aar River. Such access-restricting measures, which mark the beginning of a development strategy coordinating urban planning and transport, was facilitated by the existence of a bypass motorway already built in the 1960s, specifically to adapt to the constraints imposed by the city's site.

Another example of the interdependence between ideas and interests can be found in the Strasbourg urban area's 1975 transport development plan negotiations. The mayor of Strasbourg, Pierre Pfimlin, was firmly opposed to a «car invasion » and determined to protect the city centre's historic heritage. He seized the opportunity to repurpose a procedure intended for metropolitan-scale transport infrastructure planning (the dossier d'agglomération) to encourage the development of a large pedestrian zone in the city centre. In his opposition to the State's road engineers, who intended to develop urban motorway access to the city centre, the mayor was supported by the "urban agency"12, which acted as a mediator between the State's technical units and the municipal urbanism units. Thanks to this mediation, the urban agency's technical expertise in road engineering was applied to a development project which removed car traffic from the city centre (by constructing a bypass and loops), transformed a large part of the central city into a pedestrian area and planned a tram. By changing the subject of the procedure (initially strictly road-oriented), the urban agency demonstrated its ability to overcome the conflict between road engineers and town planners within the Ministry of Equipment over how to formulate urban questions.

\section{Conclusion: Returning to the question of change}

Based on this comparative analysis, what can we say about changes in the concepts and methods behind local urban planning and transport policy coordination? Beyond ideal visions of the city/transport coherence promoted by master plans, local stories demonstrate the importance of ideological conflicts in territorial development and transport issues, as well as the diversity of interests and how they are interrelated.

Typically, representations of land-use transport coherence are static, unlike the reality of urban policy which is characterized by a lack of synchronization between network development and urban growth, constant misalignment between existing infrastructures and their uses, and actions situated in a history (Scherrer, 2004). Transport and urban planning policies are strongly influenced by the weight of past decisions, which can prohibit local strategies from immediately adjusting to strategic changes in direction. Bern's trajectory reminds us that sectoral integration is the result of a long, conflictual process, even if this fact has been forgotten locally. Spatial planning and mobility regulation issues were a continuous source of political tension, particularly at the moment when the Helvetic Confederation decided to accord more weight to urban problems. Coordination is the result of confrontations between the areolar and reticular views of urban development, within an adaptive process that follows a constantly moving target.

These results encourage us to imagine political change differently, moving beyond the incantatory, consensual statement that better urban planning/transport coordination is necessary. We will insist here more particularly on two points.

The first point concerns the inertia of cognitive frameworks. Recent research on local planning processes has underscored the difficulty of revisiting the cognitive framework surrounding the relationship between the city and transport through the idea of sustainable development, evoking a crisis in expertise or the lack of a territorial basis for issues formulated at a global or intergenerational scale (Offner, 2003 ; Paulhiac, 2005). The difficulty of transforming this paradigm also attests to the emphasis that has been placed on accessibility in reflections on the relationships between transport networks, mobility and 
urban change. Since the 1960s, representations of coherent urban planning and transport development have been dominated by the vision of a city structured by transport networks: first road, then public transport infrastructures. By reducing the complex interactions between networks and urban areas to a simple causal relation (Offner, 1993), these representations, which are most common among transport specialists, tend to neglect other aspects of development problems such as land policy, local taxation, or economic development. Furthermore, these representations do not account for urban areas that developed away from networks. Urban sprawl may indeed be the antithesis of the sustainable city, but this does not make it any less a reality in many countries. By giving excess priority to the search for structural solutions to environmental risks, urban thought may neglect the essential question of peripheral urban areas and their inhabitants' capacity for adaptation.

Our second point concerns the instruments of public action, and we will focus here on institutional organization and planning procedures.

Coordination takes place where we do not expect it, outside purpose-built frameworks, as suggested by a comparison of local organizational dynamics. Though this observation implies that the weight of institutions as means for political change is relative, it does not deny their influence on the structure of local individual action. The specificity of the observed policies, the manner in which they insert infrastructures into the urban landscape over the long term, and the frequent emphasis placed on networks in urban territorial governance (Lorrain et Le Galès, 2004), are all facets of this institutional continuity. However, in seeking institutional reform, it is less urgent to invent new structures that are "coherent by design" than to reflect on the capacity for change in existing institutions and ways in which they can cooperate.

Coordinating urban planning and transport involves resolving misalignments, tensions, and conflicts that are far from the ideals presented in urban planning documents. However, periodically and collectively envisioning a "finished city" structured by its networks is nonetheless important since means of action are constantly defied by uses and questioned by divergent interests. In order to move beyond incantations and good intentions, the urban planning process must allow all sorts of contradictions to be voiced: those between areolar and reticular views of urban development, as well as those between the competitiveness and attractiveness of urban areas and the struggle against social inequality and environmental degradation. Urban planning should become an object of negotiation, a public space for political debate. Coordination between urban planning and transport cannot be decided by fiat, but rather by allowing certain dysfunctions to be formulated and expressed as political problems.

\section{Acknowledgements}

The authors would like to thank the National Center for Scientific Research and the French Environment and Energy Management Agency for funding the research on which this paper is based. They are also grateful to the reviewers for their valuable comments that improved the manuscript. The authors are responsible for the remaining errors.

\section{Notes}

1. Since the mid 1990s, several European projects have addressed the issue of transport and land use model integration, both from theoretical and empirical points of view. Among the main results of the TRANSLAND project (Integration of Transport and Land Use Planning), based on the comparison of several European cities, was the finding that "Land-use and transport policies are only successful with respect to criteria essential for sustainable urban transport (reduction of travel distances and reduction of share of car travel) if they make car travel less attractive (i.e. more expensive or slower)" (Wegener and Fürst, 1999) 
2. In France, urban regions are defined through a functional approach, using a commuting criterion. The « aire urbaine » includes a primary urban pole (a centre city and its suburbs) with at least 5000 jobs, plus a peri-urban space composed of municipalities where at least 40 percent of the resident active population work in this urban pole. The Swiss and French data are not entirely comparable, because there is no shared definition of the urban region. The Swiss definition is both more restrictive and more complex than the French one. Its criteria are morphological (continuity of built environment, contiguity of municipal borders), functional (commuting), and structural (type of employment, ratio of jobs to workers). The application of both definitions to the same territory, which has been done for the Geneva urban region, shows that the French definition delimits a larger space than the Swiss one, with a comparable population (Schuler, Perlik, Dessemontet, 2005).

3. Several European projects (TRANSLAND, SESAME, LEDA, DANTE, COST 332, TRANSPLUS, etc.) have contributed to knowledge of the interactions between land-use, transport supply and travel demand. They identify 'best practices' for the integration of transport planning with landuse planning and development. In 1995, a study by the Organization for Economic Cooperation and Development (OECD) and the European Conference of Ministers of Transport (ECMT) attempted to classify land-use and transport policies according to their effectiveness to reduce car dependency in cities (OECD/ECMT, 1995). The principal conclusion of the study was that "an integrated land-use transport policy approach is required to reduce automobile use and its subsequent negative consequences" (cited by Wegener and Fürst, 1999).

4. Based on a comparative study of selected European cities, the TRANSPLUS European research project identified best practices for the organization of land-use and transport measures. Among the numerous barriers to the transferability of these policies (TRANSPLUS, 2003), authors quote the lack of stability or integration of the administrative structure, the lack of implementation instruments or monitoring procedures (particularly economic instruments to capitalize land values increases), inherited mono-functional settlements (e.g. zoning criteria) or inadequate national transport infrastructure, opposition of specific stakeholders or car as a status symbol.

5. During this period, Strasbourg was chosen by the Transport Ministry as a "pilot-site" for the implementation of traffic models imported from the United States. The urban agency, in direct relation with the Ministry engineering units, carried out simulations in order to plan road infrastructures meeting the demographic and urban projections included in the SDAU.

6. As shown by referenda, which play an important part in public decisions concerning public transport or urban development, ecological values have much greater support in Germanspeaking metropolitan areas like Basel or Berne than in Geneva or Lausanne (Kaufmann et alii, 2003).

7. In France, the strong segmentation of the local administration (36 682 municipalities and four levels of local administration: municipality, inter-municipal authority, Département and Région) is frequently pointed out (by politicians, urban planners, transport experts) as a cause for the inefficiency of public action, the waste of public funds and the lack of democracy. Those arguments were used to justify recent reform of the local administration (December 2010), which aims at promoting the creation of metropolitan authorities (without suppressing municipalities) and reinforcing the role of Régions, while the continued need for the Département is being questioned.

8. The 1967 law (loi d'orientation foncière) aimed at separating master plans (SDAU) from their implementation (the definition of building rights), to ensure that land price do not rise before the development has really started. To do so, land use plans (Plans d'Occupation des Sols or POS) were dedicated to the definition of building rights according to existing equipments (Comby, 1997). In 2000, the POS has been replaced by the Local Urban Plan (PLU), which must be compatible with the new master plan (Schéma de Cohérence Territoriale or SCOT).

9. At the beginning of the 2000s, the decision by the canton of Geneva to re-launch a rail-line project between Geneva and Annemasse, in France, put an end to the negotiations with French municipalities on an earlier project to build a metro line. From that moment, the authorities of the canton spoke directly with the representatives of the French State and the Rhône-Alpes 
Région (respectively responsible for national/international and regional transport), while the municipalities (responsible for urban transport) were no more involved in the discussions. Furthermore, the municipal elected officials said they had been informed of that decision by reading the local press.

10. The Geneva Fund was established in the 1970s by negotiations between the French State, the local French municipalities, and the canton of Geneva. French municipalities close to the Swiss border were facing an influx of cross-border workers residing in France, and asked that the canton of Geneva finance public amenities. The Geneva Fund is financed at the rate of $3.5 \%$ of the total salary of French cross-border workers. It is managed by a consultative commission including elected officials from Geneva's State Council, as well as representatives of the French national and Swiss federal administrations.

11. This result was impossible to predict, considering the inconclusive results of previous referenda. Three months before this decision, a plan to construct an underground passage for pedestrians to improve conditions for car and public transport surface traffic was accepted. The results of the vote depended on the capacity of different stakeholders to rally supporters.

12. During this period, the urban agency was managed by a representative of the State who belonged to the Ponts et Chaussées civil engineering corps.

\section{References}

APEL, D., PHAROAH, T. (1995) Transport Concepts in European Cities, Avebury Studies in Green Research, Aldershot.

BRÖG, W., ERL, E., RAUX, C., JONES, P. (1996) Introduction, in CEMT (Eds), Réduire ou repenser la mobilité urbaine ? Table ronde de la Conférence Européenne des Ministres des Transports, nº102.

COMBY, J. (1997), Retour sur la loi d'orientation foncière de 1967 et ses déconvenues, Etudes Foncières, nº76, décembre 1997.

DUPUY, G. (1991), L’urbanisme des réseaux, Paris: Armand Colin, 1991.

FONTAINE, J., HASSENTEUFEL, P., (2002), Quelle sociologie du changement dans l'action publique ? Retour au terrain et refroidissement théorique, in J. FONTAINE, P. HASSENTEUFEL (Eds) To change or not to change ? Les changements de l'action publique à l'épreuve du terrain, pp. 929, Rennes: Presses Universitaires de Rennes.

FAURE, A., DOUILLET, A.- C. (Eds) (2005), L'action publique et la question territoriale, Grenoble: Presses Universitaires de Grenoble.

GALLEZ, C., KAUFMANN, V. (Eds) (2010) Mythes et pratiques de la coordination urbanismetransport, Regards croisés sur les trajectoires de quatre agglomerations suisses et françaises, Recherches INRETS n ${ }^{\circ} 281$, Paris: INRETS-Lavoisier.

GAUDIN, J.-P. (1989) La genèse de l'urbanisme de plan et la question de la modernisation politique, Revue Française de Science Politique, 39-3, pp. 296-313.

HALL, P.,TAYLOR, R. (1996), Political Science and the Three New Institutionalisms, Political Studies, 44, pp. 936-957.

JEMELIN, C., KAUfMANN, V., BARBEY, J., KLEIN, T., PINI, G. (2007) Politique de transport et inégalités sociales d'accès. Analyse comparative de huit agglomérations européennes, Lausanne: EPFL.

KAUFMANN, V., SAGER, F., FERRARI, Y., JOYE, D. (2003) Coordonner transports et urbanisme, Lausanne: Presses Polytechniques et Universitaires Romandes.

LORRAIN D., LE GALÈS, P. (2004) Gouverner les très grandes métropoles, Institutions et réseaux techniques, Revue Française d'Administration Publique, 107.

MULLER, P. (2000) L'analyse cognitive des politiques publiques: vers une sociologie politique de l'action publique, Revue Française de Science Politique, 50-2, pp. 189-208.

OECD/ECMT (1995) Urban Travel and Sustainable Development, Paris:OECD. 
OFFNER, J.-M., Les Plans de déplacements urbains (1996-2002) (2003), in D. PUMAIN, D., MATTEI, M.-F. (Eds), Données urbaines, tome 4, Paris: Anthropos, pp. 379-386.

OFFNER, J.-M. (1993) Les 'effets structurants' du transport: mythe politique, mystification scientifique, L’Espace géographique, 3, pp. 233-242.

OFFNER, J.-M. (2000) Territorial 'deregulation' : local authorities at risk from technical networks, International Journal of Urban and Regional Research, 24-1, pp. 165-181.

OFFNER, J.-M., OLLIVIER-TRIGALO, M. (2000) Introduction, in COMMISSION OF THE EUROPEAN COMMUNITY (Ed) COST 332 Transport and Land Use Policies: Innovations in Institutional Arrangements for Co-ordination, Final Report, European Commission, DG for Energy and Transport.

OLLIVIER-TRIGALO, M. (2007) Les transports en régions: doctrines, action collective et leadership, in M. OLLIVIER-TRIGALO (Ed) Six Régions à l'épreuve des politiques de transport. Décentralisation, régionalisation ferroviaire et différenciation territoriale, pp. 41-53, Synthèse INRETS n55, Paris: INRETS-Lavoisier.

OECD/ECMT (1995) Urban Travel and Sustainable Development, Paris:OECD.

PALIER, B., SUREL, Y. (2005) Les «trois i » et l'analyse de l'État en action, Revue Française de Science Politique, 55-1, pp. 7-32.

PAULHIAC, F. (2005) Mobilités urbaines à Montréal. Du renouvellement de l'action publique à la pérennité du référentiel techniciste, Cahier du LaSUR nº, Lausanne: EPFL-LASUR.

SCHERRER, F. (2004) Désynchroniser, resynchroniser, in B. LAMIZET (Ed) Les rythmes urbains, Lyon: Musée Gadagne, pp. 45-53.

SALOMON CAVIN, J. (2005) La ville mal aimée, Lausanne: Presses Polytechniques et Universitaires Romandes.

SCHULER, M., PERLIK, M., DESSEMONTET, P. (2005) Agglomérations et aires urbaines dans l'espace transfrontalier Ain - Haute-Savoie - Genève - Vaud, Observatoire statistique transfrontalier, fiche 09.

TRANSPLUS (2003) Achieving Sustainable Transport and Land Use with Integrated Policies, Final Report, European Commission (http://www.transplus.net)

WACHTER, S. (2003) La forme et le flux. Figures urbaines et architectures de la mobilité, Note du centre de prospective et de veille scientifique, $\mathrm{n}^{\circ} 18$, Paris: MELT.

WALTER, F. (2005), La montagne alpine: un dispositif esthétique et idéologique à l'échelle de l'Europe, Revue d'histoire moderne et contemporaine, 52-2, pp. 64-87.

WALTER, F. (1994), La Suisse urbaine, 1750-1950, Carouge-Genève : Zoé.

WEGENER, M., FÜRST, F. (1999), Land Use Transport Interaction : State of the Art, Deliverable 2a of the project TRANSLAND, 4th RTD Framework Programme of the European Commission, november 1999.

WIEL, M. (2002) Ville et automobile, Paris : Descartes et Cie.

ZITTOUN, P., DEMONGEOT, B. (2009) Debates in French policy studies: from cognitive to discursive approaches, Critical Policy Studies, vol. 3, n³-4, pp. 391-406. 
Table 1. Spatial distribution of the population in four urban regions (2006)

\begin{tabular}{|l|r|c|r|r|r|r|r|}
\hline & \multicolumn{3}{|c|}{ Centre city } & \multicolumn{4}{c|}{ Urban region } \\
\cline { 2 - 8 } & $\begin{array}{c}\text { Area } \\
\left(\mathrm{km}^{2}\right)\end{array}$ & $\begin{array}{c}\text { Population } \\
2006\end{array}$ & $\begin{array}{c}\text { Density } \\
(\text { pers./km })\end{array}$ & $\begin{array}{l}\text { Definition } \\
\text { of region }\end{array}$ & $\begin{array}{c}\text { Area } \\
\left(\mathrm{km}^{2}\right)\end{array}$ & $\begin{array}{c}\text { Population } \\
2006\end{array}$ & $\begin{array}{c}\text { Density } \\
(\text { pers./(km })\end{array}$ \\
\hline Bern & 52 & 122422 & 2354 & Swiss & 481 & 343789 & 715 \\
\hline Geneva & 16 & 185893 & 11618 & Swiss & 1042 & 715207 & 686 \\
\hline Strasbourg & 78 & 272975 & 3500 & French & 965 & 638670 & 662 \\
\hline Bordeaux & 45 & 232260 & 5161 & French & 2872 & 999152 & 348 \\
\hline
\end{tabular}

Sources : INSEE (RP) - OFS - Ocstat (Geneva)

Figure 1 -Bordeaux urban area

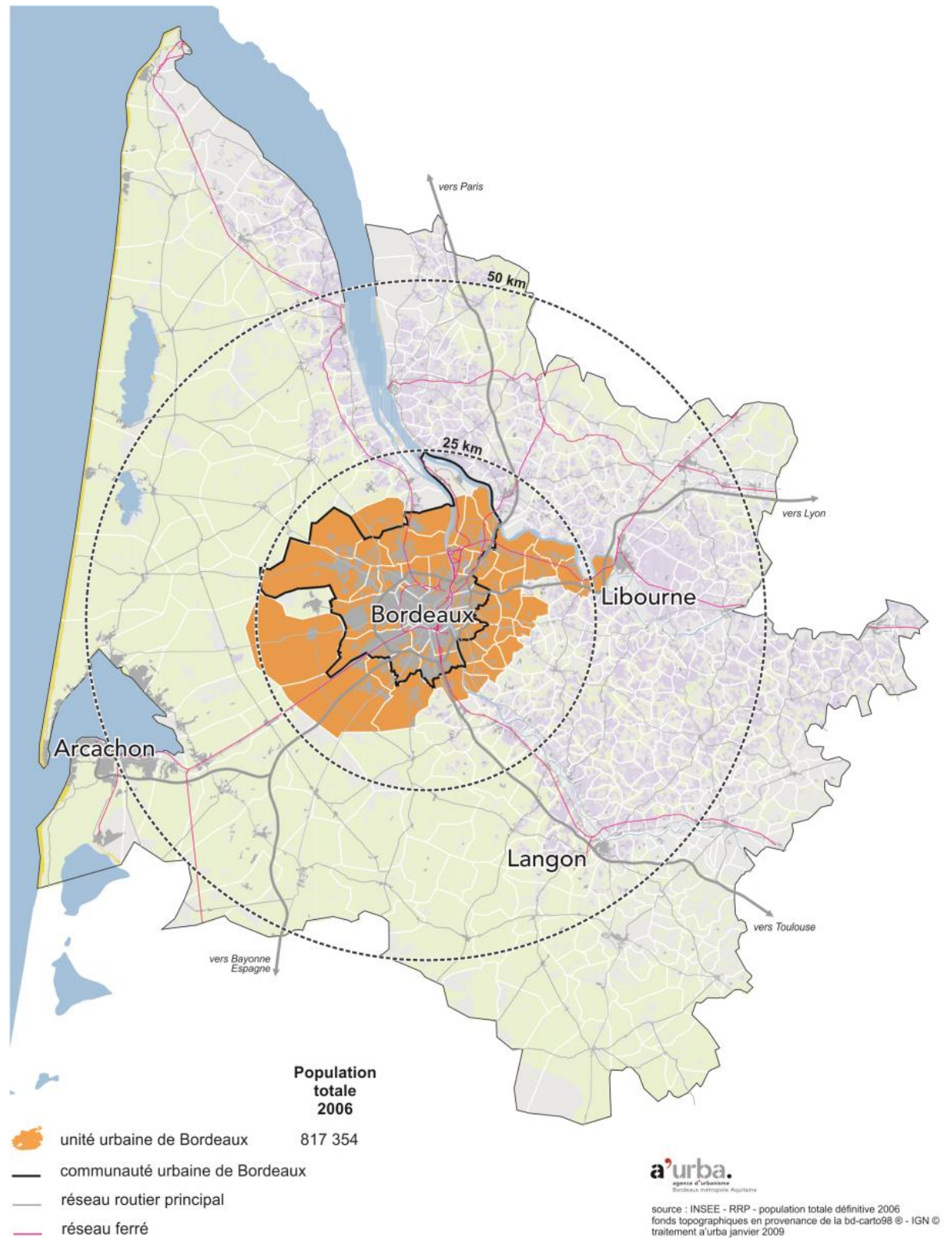

Source: a'urba, Bordeaux, 2011.

Legend: unité urbaine $=$ urban unit; communauté urbaine $=$ urban community; réseau routier principal $=$ main road network; réseau ferré $=$ rail network. 
Figure 3 - Strasbourg urban area

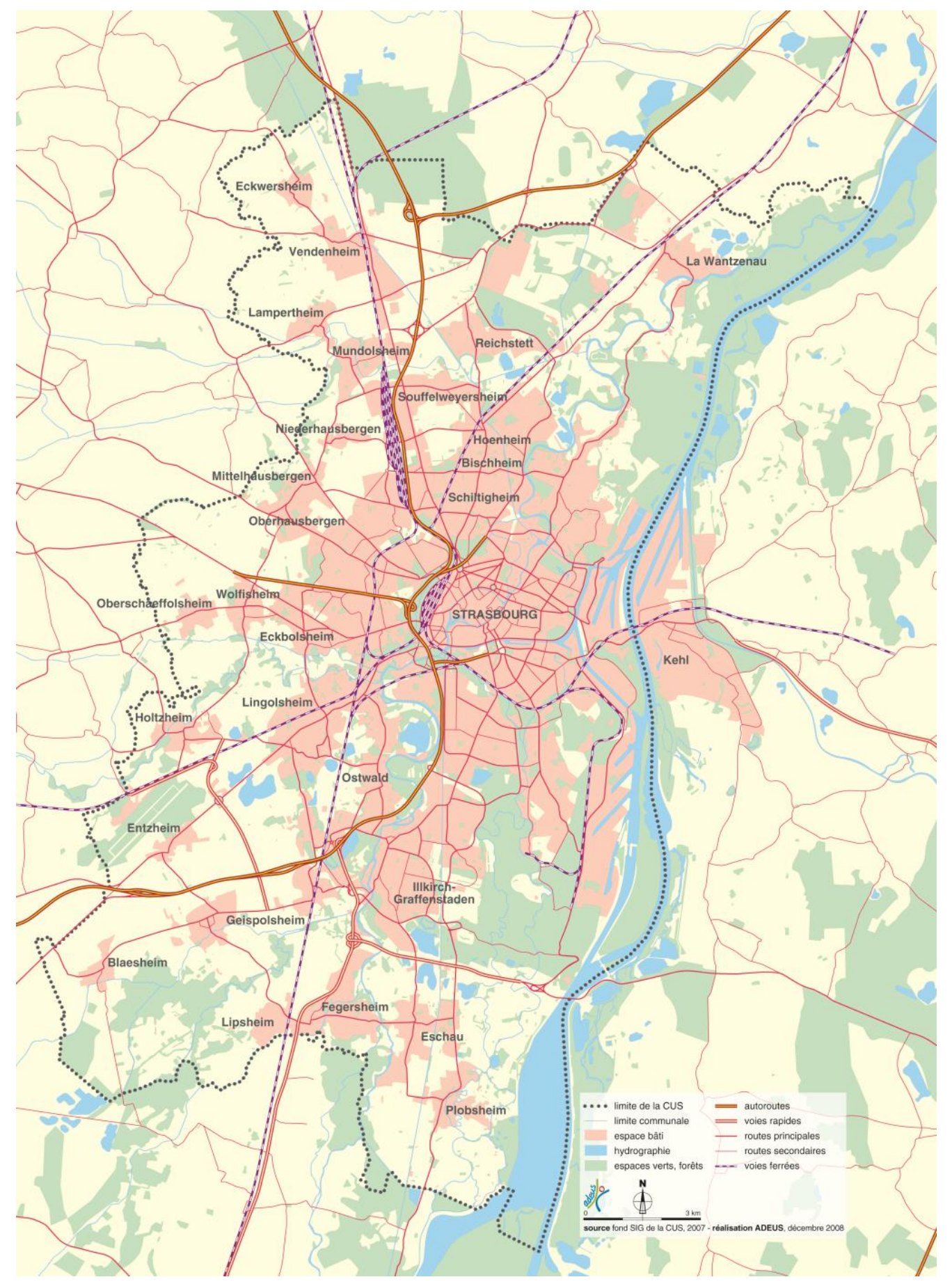

Source: Adeus, Strasbourg, 2010

Legend: CUS = Strasbourg Urban Community; limite communale = municipal administrative boundery; espace bâti : built environment; espaces verts, forêts : green spaces, forests; autoroutes : motorways; voies rapides : expressways; routes principales : main roads; routes secondaires : secondary roads; voies ferrées : railways. 
Figure 4 - Geneva urban area

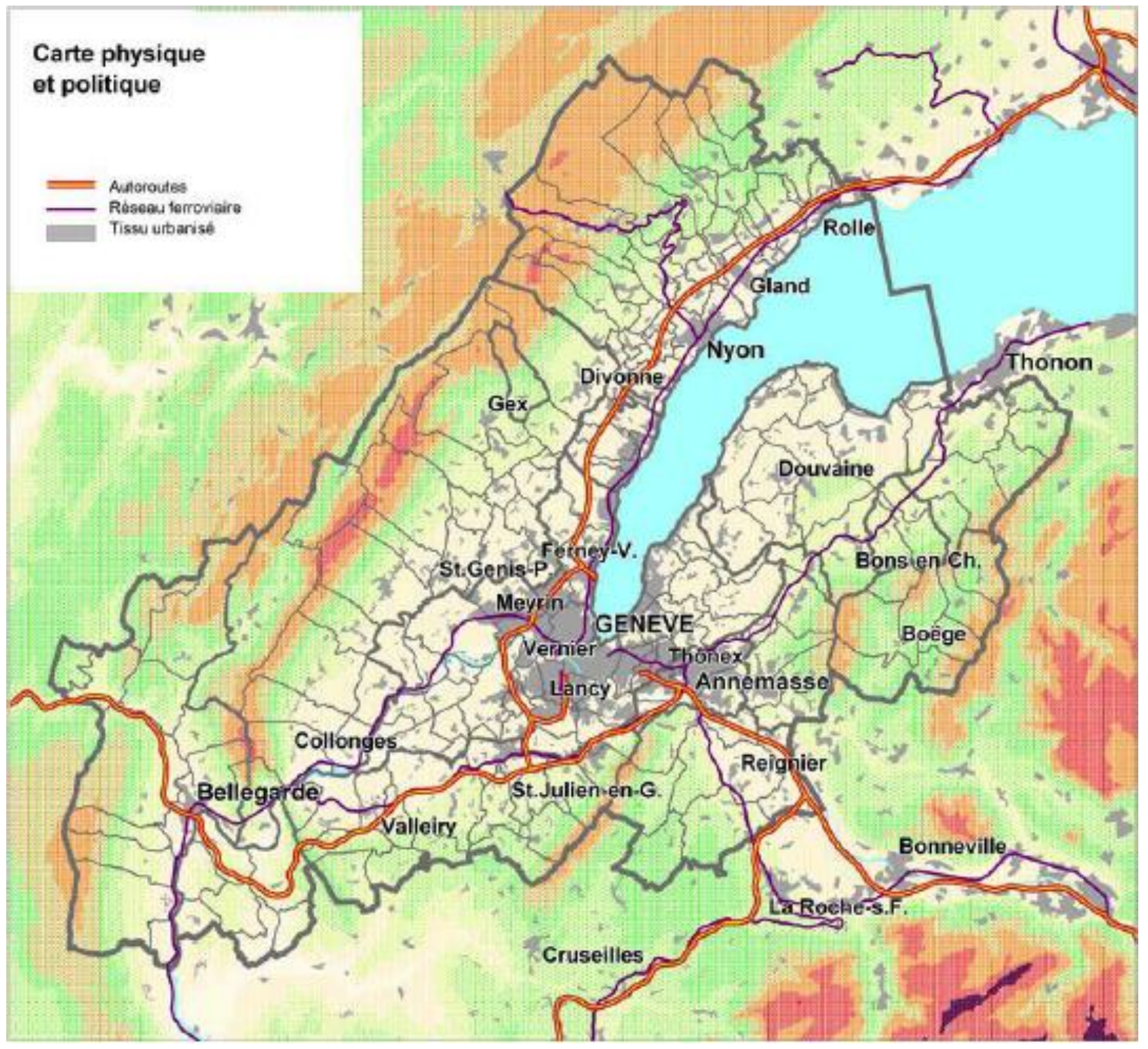

Source: Territorial Development Unit (DAT), Canton of Geneva, 2007.

Legend: Carte physique et politique: physical and political map; autoroutes = motorways; réseau ferroviaire $=$ rail network; tissu urbanisé : urbanized area; in grey : Canton of Geneva's bounderies. 